DANDELION

VOLUME 7 NUMBER I SUMMER 2016
S.D. Chrostowska is Associate Professor of Humanities and Social and Political Thought at York University, Toronto, and is the author of Permission (Dalkey Archive, 2013), Literature on Trial (University of Toronto Press, 2012), and MATCHES (Punctum, 2015). She has contributed to, among others, $B O M B$, Review of Contemporary Fiction, New German Critique, diacritics, Sub-Stance, Angelaki, and Public Culture.

\title{
Critical Longing: On Nostalgia's Role in Critique
}

\author{
S.D. Chrostowska
}

THE FOLLOWING IS PART OF THE GROUNDWORK FOR A LONGER INVESTIGATION OF THE RELATIONSHIP BETWEEN CRITIQUE AND AFFECT, SPECIFICALLY NOSTALGiC AFFECT. Occasionally, one hears mention of the 'critical value of nostalgia', or of a modern intellectual tradition that 'incorporates [a kind of] nostalgia' (which is 'reflective' and good), a tradition Svetlana Boym labelled 'off-modern'. 'Overwhelmingly, though, whether in casual remarks or scholarly studies, one hears nostalgia criticised. It seems it is enough to characterise something as nostalgic in order to dismiss it—to which expressions like 'vain, nostalgic attachment' clearly testify. This hostile critique of nostalgia is the target of those who defend nostalgia's value for us. ${ }^{2}$ Rarely, however, is that value critical value. What is missing, in my view, is a substantive and sustained account of the positive relationship between nostalgia and critique, the discursive articulation of value-commitments, particularly the social or moral kind. By suggesting 'unreflected' values (in a way melancholy, as a mood of pensiveness, associated since Aristotle's day with art and philosophy, does not), nostalgia casts doubt on one's critical bona fides. ${ }^{3}$ A recent example might serve to sum up nostalgia's reputation in critical circles: the Telos-Paul Piccone Institute titled its 2016 meeting, 'Beyond Nostalgia: Ethics, Politics, and the Critique of Modernity' - on guard against the 'lure of nostalgia'. 


\section{Critical Function? Detour via the Science of Nostalgia}

Can nostalgia play a role in the formation of a progressive critique of society? Recent scholarship on nostalgia in the sciences and the humanities has begun to question the widespread belief in its inherent conservatism. There is no consensus on whether nostalgia belongs, in some absolute or transhistorical sense, to the conservative or liberal, regressive or progressive side of the ideological spectrum, though there is little doubt that nostalgic memory is ideology-prone, or -'tainted'. What is lost in this way of focusing the questionthrough nostalgia's particular ideological ties-is the critical edge nostalgia has, I argue, long provided irrespective of political and economic loyalties. Nostalgia-critique, launched typically from the left, tends to dismiss nostalgic, nostalgia-based criticism as reactionary. By thus directing energy against explicit discursive manifestations-expressions, representations, performances-of nostalgic affect, such critique neglects the function of its own nostalgic resources (in contrast to, say, the resources of melancholy, empathy, or ressentiment) in the development of its critical practice (whether this practice is immanent critique, or arguments for radical social change, or conservative reaction against the left's unreflected appeal to romanticised, idealised pasts). So, for instance, while Critical Theory's affinities with melancholy and negative passions like dialectical, hopeful despair have been widely recognised, notably by Gillian Rose, Max Pensky, Jonathan Flatley, and most recently Robyn Marasco ${ }^{4}$-this in large part thanks to the early Frankfurt School's own embrace of melancholy as 'method' or 'disposition'-few have paused over its nostalgic roots.

Rather than embark on a substantive appreciation of nostalgia's critical (political, ethical, cultural) valences-and potential ethical, political ambivalence-I want to linger on a practical point and answer the question 'can nostalgia play a role in social critique?' with another, methodological one. How can we understand nostalgia not as an ideological position or cultural mood, but as a structuring/motivating/enabling cognitive-affective impulse for, or towards, philosophical and socio-theoretical critique? How can we write an intellectual history of nostalgia-and, more specifically, of the developmental relationship between it and critical reflection on history, culture, and the future of society-beyond simply cataloguing or describing instances of 'nostalgic thinking' and relying on psychology or neuroscience for their identification? I want to address this problem of method in connection with my current work, which stands at just this intersection of histories of affect and those of critical philosophy and social theory.

I will begin by considering three possible obstacles or resistances that might compromise such a history, having to do with prevailing concepts of affect, on the one hand, and discursivity, on the other. These obstacles are: the 'bracket of discursivity,' the 'primacy of affect,' and the 'elusiveness of affect' (the latter two important aspects of Affect Theory).

1) 'Bracket of discursivity' refers to the treatment of the discursive domain as if it were affect-free; discourse is commonly seen as referring to and producing affect but-after we exclude the conscious performance of nostalgia and the use of rhetoric to create nostalgia-effects-is itself affectively neutral, free of the pathic dynamics that may have gone into its composition and reception.

2) 'Primacy of affect' refers to the belief that discourse's treatment of affect, even in discussions devoted to it, is inevitably and irremediably reductive. More basically, this is the 'autonomy of affect' 
in Massumi's sense, the argument that 'the form/content of conventional discourse [constitutes] a separate stratum running counter to the full registering of affect and its affirmation, its positive development, its expression as and for itself' ${ }^{5}$

3) 'Elusiveness of affect' refers to a related resistance to identifying and distinguishing between particular kinds of affective experience in scientific discourse using existing scientific methods. Affect finds a home in aesthetics and politics, which renounce the futile pursuit of its containment; only in art and political action can affect be registered and appreciated in its richness, complexity, and fluidity.

I would like to propose how we can trace nostalgia's implicit (not to say subliminal) discursive operation, illuminating the histories of both affect and critical discourse. Let us first look at what we have earlier questioned as a viable method for humanistic inquiry to see what we might learn from it: the science of nostalgia.

Well over two years ago, I had the pleasure of listening to University of Southampton psychologist Tim Wildschut, a go-to guy in empirical nostalgia studies, speak about his research. I remember thinking the reported findings commonsensical and ultimately inconclusive, but remained optimistic about his insights into the 'function of nostalgia'. Since then, his collaboration with Constantine Sedikides (et alii) has received lots of media coverage in, among many other outlets, Oprah Magazine and The New Yorker. One particularly sympathetic appreciation reported Sedikides comparing nostalgia, or nostalgic remembering, to 'creating an inexhaustible bank account which is there for you if you want to withdraw from it'. 6 My sense is that, like any cultural currency, nostalgia is also not in endless supply, though perhaps, if diluted, it could hypothetically last 'forever' - as long as we understand that this dilution would come at the cost of some of its more interesting qualities.

What qualities, then, do I have in mind?

Well, for one, something that Sedikides and Wildschut have themselves identified and interpreted as nostalgia's ethical and political valences, its correlation with altruism, antimaterialism, and Gemeinschaftprecisely the values we associate with some of the greatest German representatives of the twentieth-century critical tradition. Thus, '[i]n strongly nostalgic states', Tim Adams of The Observer reports,

individuals are shown to be more likely to commit to volunteering or other expressions of altruism. Their sense of the value of money is weakened, leading them to make wilful purchases. Couples use shared nostalgia narratives to create and strengthen bonds between them. In group situations those with induced nostalgia not only tend to feel more closely bonded with the group but also more willing to form intimate associations with strangers and to be freer in their thinking. In one experiment, subjects in whom nostalgia had been induced were asked to set up a room for a meetingthose in a nostalgic frame of mind consistently set up the chairs closer than those in the control. In another experiment, those in nostalgic moods were asked to write essays, which were compared in a blind judging process with those of peers who'd had no induced feelings of nostalgia. The essays written in a nostalgic state were judged more imaginative and creative 
(storytellers, professional nostalgics, have long intuited this, not to mention poets). ${ }^{7}$

This latter tendency does not align nostalgia with critical but with creative thinking-unless, that is, you consider, as I do, the two to be intertwined. Nostalgia, in other words, can do us good. In this positive account at least, it lets us see value in what contemporary competition-driven society has degraded and is in danger of destroying.

\section{Historical Soundings}

Let us approach the 'critical function' of nostalgia in the modern period by outlining in the space of a few paragraphs nostalgia's role in the formation and animation of critical standards, hence, in the movement and development of critique.

In my larger project, I locate nostalgia within three discursive formations. They are, first, the emergence of German aesthetics, Romanticism, and Idealism; second, utopianism and critiques of society/culture in the wake of the French Revolution and industrialisation (particularly utopian social theory and experiments in intentional socialist communities); and, third, competing approaches to cultural historiography in the mid- to late-nineteenth century, especially Jules Michelet and Jacob Burckhardt. Within these, one can identify various inflections of the nostalgic mode in critical discourse, such as primitivism, the golden age, sentimentalism, the sublime, pessimism, or antiquarianism. In order to take a differentiated view of the critical-nostalgic currents in German thought, I juxtapose them with their French contemporaries. In broad outline, Romanticism, ignited by the Napoleonic wars, catalysed nostalgia's nationalistic potential. At the same time, as a protest against industrial capitalism, it did much to align nostalgia with revolution in the name of a utopian future. ${ }^{8}$ Post-revolutionary France's recurrent sense of the failure of radical political praxis put it at the frontier of utopianism. While hearkening back to that rupture in tradition (as their historical precedent, condition, and lesson), French visions of ideal society became progressively more invested in scientistic, apparently post-nostalgic futurism (e.g., Henri de Saint-Simon, Charles Fourier, Pierre-Joseph Proudhon, Louis-Auguste Blanqui). In Germany, by contrast, the Young Hegelians, radicalised by their counterparts on the right, worked out an increasingly systematic critique of modernisation and rationalisation as the proper aims of progress. They looked to the past as a quasi-mythical source of critical reflection on the alienated condition of the present and its dreams of the future. Social utopianism came to mean, first and foremost, the transformative pursuit of counter-hegemonic modes of authenticity in social relations, inspired by the vanishing heritage of earlier days and civilizations. One could indeed colligate these nostalgic and utopian phenomena under one heading, namely, the bi-directionality of modern critical discourse's affective investments, with nostalgia directed to idealised/romanticised pasts, and utopia, to imagined idealised futures.

It was in modernity, with the rise of industrial, 'producer' capitalism, that nostalgia, romancing the vanished and vanishing past, became a potent source of critical cultural standards-or, put positively, of models for emulation. In the modern paradigm, wherein (as Hans Blumenberg surmised) humankind finally came into its own as creator, emulation of the past replaced imitation, which, thanks to concepts like Progress and History, was increasingly understood as not just undesirable but impossible. Arguably the clearest and 
most influential contemporary articulation of the distinction between imitation and emulation comes from Edward Young's 1759 Conjectures on Original Composition:

Imitation is inferiority confessed; emulation is superiority contested or denied; imitation is servile, emulation generous; that fetters, this fires; that may give a name, this, a name immortal: this made Athens to succeeding ages the rule of taste, and the standard of perfection. Her men of genius struck fire against each other; and kindled, by conflict, into glories, which no time shall extinguish. We thank Eschylus for Sophocles, and Parrhasius for Zeuxis; emulation for both.

Note that the ancients are branded here as the original emulators - so that, as concerns the mode of cultural production, modern emulators still, in a sense, imitate the ancients.

That [emulation] bids us fly the general fault of imitators; bids us not be struck with the loud report of former fame, as with a knell, which damps the spirits; but, as with a trumpet, which inspires ardour to rival the renowned. Emulation exhorts us instead of learning our disciple forever, like raw troops under ancient leaders in composition, to put those laureled veterans in some hazard of losing their superior posts-in-glory. Such is emulation's high-spirited advice, such her immortalising call.

The shift of emphasis from (apparently un-evaluative) imitation to emulation is a perfect example of how the (imagined, historically recovered or reconstructed) past was nostalgically 'returned to' for ideas on which to erect new ideals. Imitation by successive ages may be relegated to the past, but emulation-for which we have to thank only the greatest, inspiring works of Antiquity - is key to the emergence of a new criterion for what should be done culturally in the present-to-future tense. The shift to cultural creativity-with increased need of critical discernment in drawing on the past, of criteria for improving on the past, rather than of rules to follow without calling them into question-this shift is plain in major cultural movements like German and French Classicism and Neoclassicism, and, importantly for us, in aesthetic criticism, where the problem of 'grounding modernity out of itself' is first raised: from the mere imitation of things Greek, to Griechensehnsucht, or Hellenic yearning, to the tyranny of Roman models, to the post-Querelle notion of modernity, which, as Jürgen Habermas writes,

assimilat[ed] [...] the aesthetic concept of perfection to that of progress as it was suggested by modern natural science. [...] [I]n opposition to the norms of an apparently timeless and absolute beauty, [the moderns] [...] elaborated the criteria of a relative or time-conditioned beauty and thus articulated the self-understanding of the French Enlightenment as an epochal new beginning. ${ }^{10}$

It was also the beginning of a new, longing look back.

An Antiquity Tour of today's Weimar shows the visitor a city engaged, in Goethe's day

not merely [in] the sober, scientifically proven reception of the antique heritage in archaeology, art and literature, but also [in] the 
emphatic recollection of a long-gone era upon which the cultural and political longings of the time were projected. This ancient Greece,

we learn, 'was an invention of modernism, in which the realities of antique tradition became the point of departure and material for new aesthetic concepts'. ${ }^{11}$ The Winckelmannian mania for the classical Greek ideal of beauty, and-through Winckelmann's increasingly ideological reception-a Kulturkritik based on adherence to the 'classical' theory of art, had to make room for a more plural culture, surer of its own standing and potential, looking back not for assurance but for inspiration and an aesthetic compass-in keeping with the ongoing need for a unified and distinct German culture to rival the ancient.

Another influential discursive locus of the distinction between imitation and emulation was of course J.G. Herder, who also helped reconceive ahistorical Nachahmung (imitation) as historical, creative Nachfolge (emulation) and Übertragung (cultural transfer) - offering a superior alternative not only to the derivative Classicist model but also to anti-Neoclassical poetics of genius and to cultural death. ${ }^{12}$ Ch.M. Wieland, whose Classicism (so important for Schiller's aesthetic education) became apparently increasingly critical over time, "did not see the "Grecian" as the ideal human being [...] but rather as "the human being" per se', warts and all. His use of the past is described by the Weimar Classics Foundation as holding up a mirror to his own times: 'he understood his critical reconstruction and reception of antiquity as a critique of the present'. ${ }^{13}$ The clearest articulation of this emulative critique of the present would eventually come from the pen of the young Friedrich Nietzsche, with German culture as a reincarnation of pre-classical values:

\begin{abstract}
At the same time we feel that the birth of a tragic age means the return of the German spirit to itself, a blissful reunion [...] Now, at long last, having returned to the original spring of its being, that spirit can dare to walk, bold and free, before all other peoples, without the leading-reins of Latin civilization; provided, of course, that the German spirit goes on learning, unceasingly, from the Greeks, for the ability to learn from this people is in itself a matter of lofty fame and distinguishing rarity. And when was our need of these supreme teachers greater than now, as we are experiencing the rebirth of tragedy and yet are in danger of not knowing whence it comes, nor of being able to discern where it wants to go? ${ }^{14}$
\end{abstract}

But this past is only an indirect object of longing, the real object being the future, which Nietzsche serenades rhapsodically in the same work. In On the Genealogy of Morals, the past-known, like all else, only perspectivally (willfully, emotionally) - is valuable as a source of 'aristocratic' values before 'good and evil,' of 'Roman' ideals reclaimable for the present, and overcome. The past sets a bar, rather than a positive standard, for the redemptive future.

If it were thought possible to resurrect the past, to bring back its institutions or ideals, perceived as more stable or grounded relative to the present; if it were possible to restore authentic nature glimpsed in ancient and medieval ruins - as opposed to 'ugly', 'unclean' modern nature - it is safe to say that nostalgia would not have been felt so acutely. Thrown into relief by an ever-sharper sense of historical discontinuity, the past could now be longed for, be it uncritically-indiscriminately, as a whole, or critically-discerningly, in its parts. The emerging critical perspective on the past, a time now seen as irretrievable, also made its return or reproduction more undesirable than 
before. Instead, what increasingly excited the modern imagination was a punctuated return not of but to that past (through the window of literary and visual representation, and, later, through its recreation in themed environments), without the risk of contaminating the present. Modern critique, then, was part and parcel of the modern attitude, of its affectivereflective (i.e., emotive-evaluative) conjuncture. It was a projection into the future of a desire for the best of the past. In the most general terms, it articulated a concern about the specificity of the present, its contribution to human progress relative to the past, and its prospects for improving on that past.

Nostalgia thus evolved from a pathology not of reason but of the imagination-from a pathologised measure of longing and response to the passage of time-to a malaise of dissatisfaction with the present and the direction that present was taking, to eventually providing the basis for a productive and (on one side at least) critical cultural stance. One positive function of nostalgia is, then, to recuperate past values while transforming their function and application. This rather selective use of collective feeling has taken root in a civilization that rightly or wrongly regards itself as the be-alland-end-all of rational social progress. One could even say that such exploitation and manipulation of nostalgia is not just of its place, but also of its time-inseparable from the idea of rational utopia (conceived negatively or positively cast).

The 'melancholy science' of the Frankfurt School, epitomised by Th.W. Adorno, is to-date arguably the most explicit and radical theoretical elaboration of this close historical relationship between critique and past-directed affect, between (in this case, negative) dialectics and the oblique movement of longing. ${ }^{15}$ Both these elements avoid coming down squarely on one side of any argument, and operate instead on the logic of valency or elective affinity, in the sense of affectively bonding with particular objects.

\section{Problems and Methods}

We can finally return to the problem with which I began: how to move past the three obstacles to integrating the history of discourses and affects in an alternative approach. It is not easy to see how one might tackle the historical analysis of discourse starting from exactly the opposite assumptions: first, that discourse is in effect structured by and permeated by traces of affect; second, that affects can stretch themselves out in written discourse to their full extent (to be sure differently than in other situations and mediums), and moreover, are sustained and transformed by their discursive experience; and, third, that they can be retrospectively discursively defined and identified, that they are 'capturable' and 'sortable' by discourse insofar as their workings within it both affect and are affected by discursive practice.

Clearly, there are problems with all three counter-assumptions, which leaves us to either finesse them or to look elsewhere for a creative solution. Thus, the second obstacle (the 'primacy of affect') can be sidestepped by accepting the limitations of affect's presence in discourse, which is the interface between affect and meaning, the latter essential to any thick account of nostalgic experience. The third obstacle (the 'elusiveness of affect') can be dealt with by noting, for instance, that tagging and collecting evidence of nostalgia in discourse does not much help with uncovering nostalgia's role in the emergence of critical ideas, let alone its role in the structure of argument and the formation of critical standards. Laying the basis for nostalgia's intellectual 
history requires not only pointing out that nostalgic experience can be reliably identified in discourse by others than those experiencing it and described from the outside; more than this, what is needed is a change of analytic that grants nostalgia a reflective dimension and structure, broadening our definition of nostalgia in the process to a positive affective relation to and reflection on the past, a 'thinking-feeling'. The reflective dimension includes images and memories, without which nostalgia would manifest as a vague, objectless, diffuse yearning, on the model of melancholy. We cannot begin to trace the nostalgic currents running through critical discourse without conceding nostalgia's discursive rationality, its ability to colour, structure, and orient orin Martha Nussbaum's view-internally constitute rational value-judgment, and affect communication (which amounts to no more than that it can influence our thinking to the point of entering into it, such that we are 'philosophising from within a mood' of nostalgia). ${ }^{16}$ The new optic I am proposing answers the first objection not by opening the 'bracket of discursivity', but by showing that it was never properly closed. If we are prepared to admit that discursive acts are typically motivated, not only as to their purpose but as to their reasons, these stemming not just from incentive structures but also from the structure of desire, emotional states, moral feelings, and even conatus - if we grant this, then we are compelled to allow that affect undergirds as well as feeds into how we judge, what we think and write. It is enough to consider literary critics; surely they have not left their emotions at the door of their profession and simply injected the bile for effect?

Nostalgia, then, is a complex experience that involves not only 'valuefeeling', but also 'value-thinking'. For critics of the culture of their own time, disaffection with the present and with the future extrapolated from it has its emotional counterpart in affection for aspects of an earlier time, another form of social life, organisation, etc. More basically, any appeal to values is an appeal to the past-one that often, when conscious, avails itself of a fallacy, let us call it the pathetic-genetic fallacy, which goes something like this: the past forged in its own crucible criteria that reflected its organic development, as its 'second nature', criteria we can reflect on but claim only 'unnaturally' - not only because these criteria do not originate with us, but because it is in our 'second nature' to invent, to create, rather than to appropriate. I see this fallacy at work in Nietzsche's 'master morality', or in Spengler, who came up with a metahistorical distinction between natural 'culture', 'permeated with soul' (e.g., that of ancient Greece), and artificial, intellectual 'civilization' (e.g., the Roman) to describe cultural history as the 'waxing and waning of organic forms' ${ }^{17}$ The pathetic-genetic fallacy, then, has it that certain past valuecommitments and standards of evaluation, although far from having been realised in the past, were an authentic expression of their time, and that, secondly, however admirable they are, their simple imitation in the present will not do, not to mention be doable paradigmatically speaking. Values can be transmitted and continuous, rooted in a living tradition, but not deliberately resuscitated and still remain credible. At the same time, their historic value qua values is upheld.

To the nostalgia for lost past 'civilizations', 'periods', or 'spirits' is thus added the 'axiological' nostalgia for the origins of values, when the latter were pure, firm, noble, unchallenged. A seminal critical-creative work like the Genealogy calls for historical innovation in the realm of moral values-paving the way, from the standpoint of an earlier, nobler value-system, for a new revaluation to undo the damage of the earlier one. ${ }^{18}$ 
In this sense, one can see the historical elaboration of criticism (extending to historiographic and critical modes themselves) as being in tandem with the intensification of nostalgic sentiment. Only more recently has the nostalgic image or reconstruction of the past been subjected to critical scrutiny, and whole traditions revealed as invented (to allude to Hobsbawm and Ranger). Yet this does not make hallowed criteria and values qua cultural artifacts with a rich, often institutional history-criteria and values like humanity, civilization, reason, progress, autonomy-any less valuable, since we have been no mere imitators of the past; we have been critically modern. We have grasped how selectively societies remember and modernity forgets (recalling the titles of Paul Connerton's seminal contributions), but we still cherish our sense of the past, longingly scan the receding horizon behind which it lies for inspiration and critical perspectives on (to invoke François Hartog and H.U. Gumbrecht) our 'presentist present', our 'broad present'-flooded by indiscernible 'pasts', multiple simultaneities, confronted with a closed futurity.

How, then, might we trace the motivating critical operation of this nostalgia in discourse? The principal challenge of such an undertaking would be to develop a historical method whereby texts can be illuminated and illuminate one another not on the level of content or language (as in deconstruction), but on the level of affectively charged rhetorical moves, repositionings, concretisations, and overall argumentative thrusts. ${ }^{19}$ In practice, this would mean looking at how nostalgia is embedded in signs on the page: examining the structure of argument, the criteria invoked or implicit, and finally their relations, the criterial architecture and hierarchy (which criteria relate to which, which are higher-order, which are foundational, load-bearing, which are idiosyncratic elaborations, which are shared). In this context, one could hardly ask for a more fitting analytic concept than Raymond Williams's structure of feeling-as different from other structures like 'mentality', 'worldview', 'ideology', or even social attitudes. Let us remember that this affective structure, 'at the very edge of semantic availability', ${ }^{20}$ consists in 'characteristic elements of impulse, restraint, and tone,' in 'particular linkages, [...] emphases and suppressions, and, in what are often its most recognisable forms, particular deep starting-points and conclusions'. ${ }^{21}$ It is made up of

specifically affective elements of consciousness and relationships: not feeling against thought, but thought as felt and feeling as thought: practical consciousness of a present kind, in a living and interrelating continuity. We are then defining these elements as a 'structure'-as a set, with specific internal relations, at once interlocking and in tension. Yet we are also defining a social experience which is still in process, often indeed not yet recognised as social but taken to be private, idiosyncratic, and even isolating, but which in analysis (though rarely otherwise) has its emergent, connecting, and dominant characteristics, indeed its specific hierarchies. ${ }^{22}$

In searching for nostalgia in critique, do I not have in mind uncovering some of this structure of social affective experience-this broadly "creative response' to life as it (barely) comes to the surface of expression in a particular cultural domain, this 'very deep and very wide possession' subtending all communication, the critical no less than the lyrical? ${ }^{23}$ A history of 'nostalgic criticism' cannot consist merely in confirming and elaborating on the presence of nostalgia in the normative reflection on society. Rather, the account must examine nostalgia's internally structuring role, its historical discursive and rhetorical force in specific critical articulations. At a time when, perhaps more 
than ever, critique relies for its resources on the work of passionate and hopeful retrieval from obscurity and oblivion of past ideas, concepts, and values, as precedents, forerunners, resources, and creative spurs-at such a time, a reflection on the critical function of nostalgia is plainly in order.

York University, Toronto

\section{Notes}

Svetlana Boym, The Future of Nostalgia (New York: Basic, 2001), pp. xvi-xvii; see also pp. 22-31.

On the history of the use and abuse of 'nostalgia' as a negative critical category, see Nauman Naqvi, "The Nostalgic Subject: A Genealogy of the "Critique of Nostalgia", C.I.R.S.D.I.G. working paper (p. 23) < http://www.cirsdig.it/Pubblicazioni/naqvi.pdf> [accessed 16 July 2016].

On melancholy, see for example Raymond Klibansky, Erwin Panofsky, and Fritz Saxl, Saturn and Melancholy: Studies in the History of Natural Philosophy, Religion, and Art (New York: Basic, 1964). Immanuel Kant-who largely defined the modern meaning of 'critique'-has long been associated with a melancholy cast of mind, his observations on the subject in the Anthropology notwithstanding. In that work, he distinguishes, first of all, between mere propensity and condition, classes melancholy as a 'temperament of feeling,' as an ailment of the cognitive faculty that he equates (as melancholia, or Tiefsinningkeit) with 'a mere delusion of misery' proper to 'the gloomy self-tormentor (inclined to worry),' leading to mental disorder, which is to say to melancholy qua hypochondria. Immanuel Kant, Anthropology from a Pragmatic Point of View, ed. and trans. by Robert B. Louden (Cambridge, UK: Cambridge University Press, 2006), p. 187, p. 107, p. 96. Interestingly for us, Kant also devotes a paragraph to nostalgia ('homesickness'), which he regards as a sensory product of the faculty of affinity and, above all, as a curiosity [pp. 71-72].

An indisputable authority on Kantian melancholy, Jean-Baptiste Botul used Kant's nonexistent sex life as a departure point for his thesis about the means of philosophical reproduction: 'philosophers do not penetrate, they withdraw. This withdrawal has a name: melancholy,' 'a malady of solitude.' Jean-Baptiste Botul, La vie sexuelle d'Emmanuel Kant (Paris: Fayard, 1999), p. 32 (my trans.). The work may have been a hoax (its real author, one Frédéric Pagès), yet the observation falls in the tradition of type-casting the profoundly thoughtful male as a melancholic.

Gillian Rose, The Melancholy Science: An Introduction to the Thought of Theodor W. Adorno (London: Macmillan, 1978); Max Pensky, Melancholy Dialectics: Walter Benjamin and the Play of Mourning (Amherst: University of Massachusetts Press, 2001); Jonathan Flatley, Affective Mapping: Melancholia and the Politics of Modernism (Cambridge, MA: Harvard University Press, 2008); Robyn Marasco, The Highway of Despair: Critical Theory after Hegel (New York: Columbia University Press, 2015). Brian Massumi, 'The Autonomy of Affect', Cultural Critique, 31 (1995), p. 89.

Quoted in Tim Adams, 'Looking Back in Joy: The Power of Nostalgia', Observer, Nov. 9, 2014, <http://www.theguardian.com/society/2014/nov/09/look-back-in-joy-thepower-of-nostalgia $>$ [accessed 16 June 2016].

Ibid.

This 'revolutionary romanticism' - a form of 'modernity's cultural self-criticism' 'in the name of certain values of the past'- 'integrates the conquests of 1789 (liberty, democracy, equality) and whose goal is not a return in time but a detour through the communitarian past towards a utopian future.' Michael Löwy and Max Blechman, 'Qu'est-ce que le romantisme révolutionnaire?,' in Europe: Revue littéraire mensuelle: Le Romantisme révolutionnaire 82.900 (2004), p. 4 (my trans.). Cf. M. Löwy and Robert Sayre, Révolte et mélancolie. Le romantisme à contre-courant de la modernité (Paris: Payot, 1992). 
Edward Young, Conjectures on Original Composition: In a Letter to the Author of Sir Charles Grandison (London: Millar and Dodsley, 1759), pp. 65-67.

Jürgen Habermas, 'Lecture 1: Modernity's Consciousness of Time and Its Need for SelfReassurance,' in The Philosophical Discourse of Modernity: Twelve Lectures, trans. by Frederick G. Lawrence (Cambridge, UK: Polity, 1987), p. 8, my emphases.

KSW [Weimar Classics Foundation], 'Tour Antiquity, Arcadia and Ilm Athens: Reception of Antiquity in Weimar,' < http://www.klassikstiftung.de/uploads/tx_lombpointofinterest/KSW-Tour6-Antike-E_01.pdf $>$ [accessed 16 June 2016] (p. 1), my emphasis. See Johann Gottfried Herder, 'Vorrede,' Ueber Thomas Abbts Schriften: Der Torso von einem Denkmaal, an seinem Grabe errichtet (Leipzig: Hartknoch, 1768), pp. 9-10. KSW, ‘Tour,' p. 7.

Friedrich Nietzsche, The Birth of Tragedy, ed. by Raymond Geuss and Ronald Speirs, trans. by Ronald Speirs (Cambridge, UK: Cambridge University Press, 1999), p. 95, sec. 19.

No passage in Adorno's work throws this link into sharper relief than the opening of Minima Moralia: 'The melancholy [traurige - the antonym of fröhliche] science from which I make this offering to my friend relates to a region that from time immemorial was regarded as the true field of philosophy, but which, since the latter's conversion into method, has lapsed into intellectual neglect, sententious whimsy and finally oblivion: the teaching of the good life.' Theodor W. Adorno, Minima Moralia: Reflections on a Damaged Life, trans. by E.F.N. Jephcott (New York: Verso, 2005), p. 15.

See Jeff Malpas, 'Philosophy's Nostalgia,' in Contributions to Phenomenology 63.1 (2011), pp. 87-101 (special issue: 'Philosophy's Moods: The Affective Grounds of Thinking,' ed. by Hagi Kenaan and Ilit Ferber). It was Martin Heidegger who drew attention to philosophy's fundamentally nostalgic - and not only melancholy-attunement in his Fundamental Concepts of Metaphysics: World, Finitude, Solitude, trans. by William McNeill and Nicholas Walker (Bloomington: Indiana University Press, 1995), pp. 4-9. Heidegger speaks here of 'melancholy' (Schwermut) as being in 'exceptional proximity' to philosophy, at once affecting its form and 'prescrib[ing] a fundamental attunement which delimits its substantive content' (pp. 182-183). But it is 'homesickness' (Heimweh) that he names as the 'very determination of philosophy' (p. 5).

See Oswald Spengler, Man and Technics: A Contribution to a Philosophy of Life, trans. by Charles Francis Atkinson (Westport, CT: Greenwood, 1976), p. 38; The Decline of the West, vol. 1, Form and Actuality, trans. by Charles Francis Atkinson (New York: Knopf, 1944), p. 22

See especially ch. 2 of Hans Joas, The Genesis of Values, trans. by Gregory Moore (Chicago: University of Chicago Press, 2000). Regardless of the retrospective or objective 'implausibility' (p. 34) of Nietzsche's account of the genesis of moral values, Joas's account draws attention to the historical link between nostalgic sentiment (sense of waning or loss) and the problematisation of values, Nietzschean questioning above all (p. 20).

For a clear-eyed discussion of 'nostalgic rhetoric' stressing the need for a constructive 'nostalgia critique,' one that not only recognises the need to move beyond both nostalgia's wholesale dismissal and facile divisions into 'good and bad nostalgia,' in order to 'acknowledg[e] the diversity of personal needs and political desires' motivating nostalgic responses, but that also makes a case for unearthing a 'single [nostalgic] structure of rhetoric,' see Stuart Tannock, 'Nostalgia Critique', Cultural Studies 9.3 (1995), 453-464 (p. 461). Raymond Williams, Marxism and Literature (Oxford: Oxford University Press, 1977), p. 134. Ibid., p. 132, p. 134

Ibid., p. 132.

Raymond Williams, 'The Analysis of Culture', in The Long Revolution (New York: Penguin, 1961), p. 65. 


\section{Works Cited}

Adams, Tim, 'Looking Back in Joy: The Power of Nostalgia', Observer. Nov. 9, $2014<$ http://www.theguardian.com/society/2014/nov/09/look-backin-joy-the-power-of-nostalgia > [accessed 16 June 2016]

Adorno, Theodor W, Minima Moralia: Reflections on a Damaged Life, trans. by E.F.N. Jephcott (New York: Verso, 2005)

Botul, Jean-Baptiste, La vie sexuelle d'Emmanuel Kant (Paris: Fayard, 1999)

Boym, Svetlana, The Future of Nostalgia (New York: Basic, 2001)

Gumbrecht, Hans Ulrich, Our Broad Present: Time and Contemporary Culture (New York: Columbia University Press, 2014)

Habermas, Jürgen, The Philosophical Discourse of Modernity: Twelve Lectures, trans. by Frederick G. Lawrence (Cambridge, UK: Polity, 1987)

Hartog, François, Regimes of Historicity: Presentism and Experiences of Time, trans. by Saskia Brown (New York: Columbia University Press, 2015)

Heidegger, Martin, Fundamental Concepts of Metaphysics: World, Finitude, Solitude, trans. by William McNeill and Nicholas Walker (Bloomington: Indiana University Press, 1995)

Kant, Immanuel, Anthropology from a Pragmatic Point of View, ed. and trans. by Robert B. Louden (Cambridge, UK: Cambridge University Press, 2006)

Klassik Stiftung Weimar, 'Tour Antiquity, Arcadia and Ilm Athens: Reception of Antiquity in Weimar' < http://www.klassikstiftung.de/uploads/tx_lombpointofinterest/KSW-Tour6-AntikeE_01.pdf > [accessed 16 June 2016]

Löwy, Michael, and Max Blechman, 'Qu'est-ce que le romantisme révolutionnaire?', Europe: Revue littéraire mensuelle: Le Romantisme révolutionnaire, 82.900 (2004), 3-5

Massumi, Brian, 'The Autonomy of Affect', Cultural Critique, 31 (1995), 83-109

Nietzsche, Friedrich, The Birth of Tragedy, trans. by Ronald Speirs, ed. by Raymond Geuss and Ronald Speirs (Cambridge, UK: Cambridge University Press, 1999)

Tannock, Stuart, 'Nostalgia Critique', Cultural Studies, 9.3 (1995), 453-464

Williams, Raymond, The Long Revolution (New York: Penguin, 1961)

-, Marxism and Literature (Oxford: Oxford University Press, 1977)

Young, Edward, Conjectures on Original Composition: In a Letter to the Author of Sir Charles Grandison (London: Millar and Dodsley, 1759) 